\title{
Front Matter: Volume 8627
}

, "Front Matter: Volume 8627," Proc. SPIE 8627, Integrated Optics: Devices, Materials, and Technologies XVII, 862701 (9 April 2013); doi:

$10.1117 / 12.2025001$

SPIE. Event: SPIE OPTO, 2013, San Francisco, California, United States 


\title{
PROCEEDINGS OF SPIE
}

\section{Integrated Optics: Devices, Materials, and Technologies XVII}

\author{
Jean Emmanuel Broquin \\ Gualtiero Nunzi Conti \\ Editors
}

\author{
5-7 February 2013 \\ San Francisco, California, United States
}

Sponsored and Published by

SPIE 
The papers included in this volume were part of the technical conference cited on the cover and title page. Papers were selected and subject to review by the editors and conference program committee. Some conference presentations may not be available for publication. The papers published in these proceedings reflect the work and thoughts of the authors and are published herein as submitted. The publisher is not responsible for the validity of the information or for any outcomes resulting from reliance thereon.

Please use the following format to cite material from this book:

Author(s), "Title of Paper," in Integrated Optics: Devices, Materials, and Technologies XVII, edited by Jean Emmanuel Broquin, Gualtiero Nunzi Conti, Proceedings of SPIE Vol. 8627 (SPIE, Bellingham, WA, 2013) Article CID Number.

ISSN: 0277-786X

ISBN: 9780819493965

Published by

SPIE

P.O. Box 10, Bellingham, Washington 98227-0010 USA

Telephone +1 3606763290 (Pacific Time) · Fax +1 3606471445

SPIE.org

Copyright (c) 2013, Society of Photo-Optical Instrumentation Engineers.

Copying of material in this book for internal or personal use, or for the internal or personal use of specific clients, beyond the fair use provisions granted by the U.S. Copyright Law is authorized by SPIE subject to payment of copying fees. The Transactional Reporting Service base fee for this volume is $\$ 18.00$ per article (or portion thereof), which should be paid directly to the Copyright Clearance Center (CCC), 222 Rosewood Drive, Danvers, MA 01923. Payment may also be made electronically through CCC Online at copyright.com. Other copying for republication, resale, advertising or promotion, or any form of systematic or multiple reproduction of any material in this book is prohibited except with permission in writing from the publisher. The CCC fee code is 0277-786X/13/\$18.00.

Printed in the United States of America.

Publication of record for individual papers is online in the SPIE Digital Library.

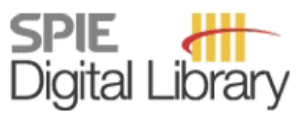

SPIEDigitalLibrary.org

Paper Numbering: Proceedings of SPIE follow an e-First publication model, with papers published first online and then in print and on CD-ROM. Papers are published as they are submitted

and meet publication criteria. A unique, consistent, permanent citation identifier (CID) number is assigned to each article at the time of the first publication. Utilization of CIDs allows articles to be fully citable as soon as they are published online, and connects the same identifier to all online, print, and electronic versions of the publication. SPIE uses a six-digit CID article numbering system in which:

- The first four digits correspond to the SPIE volume number.

- The last two digits indicate publication order within the volume using a Base 36 numbering

system employing both numerals and letters. These two-number sets start with 00, 01, 02, 03, 04, $05,06,07,08,09,0 A, 0 B \ldots 0 Z$, followed by 10-1Z, 20-2Z, etc.

The CID Number appears on each page of the manuscript. The complete citation is used on the first page, and an abbreviated version on subsequent pages. Numbers in the index correspond to the last two digits of the six-digit CID Number. 


\title{
Contents
}

\author{
ix Conference Committee \\ xi Introduction \\ xiii Group IV photonics for the mid infrared (Plenary Paper) [8629-1] \\ R. Soref, The Univ. of Massachusetts at Boston (United States)
}

xxix Light in a twist: optical angular momentum (Plenary Paper) [8637-2]

M. J. Padgett, Univ. of Glasgow (United Kingdom)

\section{SESSION 1 WAVEGUIDE ENGINEERING I}

862703 Optical spectrum control circuit with flat pass band characteristics using a high-resolution arrayed-waveguide grating [8627-2]

T. Ikeda, Keio Univ. (Japan); T. Mizuno, H. Takahashi, NTT Corp. (Japan); H. Tsuda, Keio Univ. (Japan)

862705 Single- and double-energy $\mathbf{N}^{+}$- irradiated planar waveguides in eulytine and sillenite type BGO crystals [8627-4]

I. Bányász, Wigner Research Ctr. for Physics (Hungary); Z. Zolnai, Research Institute for Technical Physics and Materials Science (Hungary); S. Pelli, Istituto di Fisica Applicata Nello Carrara (Italy); S. Berneschi, Museo Storica della Fisica e Ctr. Studi e Ricerche Enrico Fermi (Italy) and Istituto di Fisica Applicata Nello Carrara (Italy); M. Fried, T. Lohner, Research Institute for Technical Physics and Materials Science (Hungary); G. Nunzi-Conti, Istituto di Fisica Applicata Nello Carrara (Italy); G. C. Righini, Museo Storica della Fisica e Ctr. Studi e Ricerche Enrico Fermi (Italy) and Istituto di Fisica Applicata Nello Carrara (Italy)

\section{SESSION 2 PHOTONIC INTEGRATION}

$862707 \mathrm{III}-\mathrm{V} /$ silicon photonic integrated circuits for communication and sensing applications (Invited Paper) [8627-6]

G. Roelkens, S. Keyvaninia, S. Stankovic, Y. De Koninck, M. Tassaert, P. Mechet, T. Spuesens, N. Hattasan, A. Gassenq, M. Muneeb, E. Ryckeboer, S. Ghosh, D. Van Thourhout, R. Baets, Univ. Gent (Belgium)

862708 Design and experimental characterization of an InP photonic integrated circuit working as a receiver for frequency-modulated direct-detection microwave photonic links [8627-7] J. S. Fandiño, Univ. Politécnica de Valencia (Spain); J. D. Doménech, Univ. Politécnica de Valencia (Spain) and VLC Photonics (Spain); P. Muñoz, J. Capmany, Univ. Politécnica de Valencia (Spain) 
8627 OA Optofluidic fiber optic [8627-10]

G. Testa, G. Persichetti, R. Bernini, Istituto per il Rilevamento Elettromagnetico dell'Ambiente, CNR (Italy)

8627 OB Low cross-talk polarization splitter on glass [8627-11]

F. Parsy, E. Ghibaudo, J.-E. Broquin, IMEP-LAHC (France)

8627 OD Filtering of radially polarized beams by microsphere-chain waveguides [8627-13]

A. Darafsheh, The Univ. of North Carolina at Charlotte (United States); N. I. Limberopoulos, Air Force Research Lab. (United States); A. Lupu, Institut d'Électronique Fondamentale, CNRS (France); V. N. Astratov, The Univ. of North Carolina at Charlotte (United States) and Air Force Research Lab. (United States)

\section{SESSION 4 ON CHIP ACTIVE DEVICES}

8627 OE Integrated InP based modelocked lasers and pulse shapers (Invited Paper) [8627-14] E. Bente, S. Tahvili, V. Moskalenko, S. Latkowski, Technische Univ. Eindhoven (Netherlands); M. Wale, Technische Univ. Eindhoven (Netherlands) and Oclaro, Inc. (United Kingdom); J. Javaloyes, Univ. de les Illes Balears (Spain); P. Landais, Dublin City Univ. (Ireland); M. Smit, Technische Univ. Eindhoven (Netherlands)

8627 OF Q-switched distributed-Bragg-reflector ytterbium laser [8627-15]

H. Ouslimani, L. Bastard, J.-E. Broquin, IMEP-LAHC, CNRS, Univ. de Grenoble Alpes (France)

$8627 \mathrm{OH}$ Analysis of the light coupling between nano-waveguides made of tellurite glasses [8627-17]

J. Córdoba-Ramírez, H. E. Hernandez-Figueroa, Univ. Estadual de Campinas (Brazil); F. Amaya-Fernández, Univ. Pontificia Bolivariana (Colombia); J. D. Marconi, Univ. Federal do ABC (Brazil); H. L. Fragnito, Univ. Estadual de Campinas (Brazil)

\section{SESSION 5 SENSORS}

8627 Ol Spectroscopy-on-chip applications of silicon photonics (Invited Paper) [8627-18]

R. Baets, A. Z. Subramanian, A. Dhakal, S. K. Selvaraja, K. Komorowska, F. Peyskens,

E. Ryckeboer, N. Yebo, G. Roelkens, N. Le Thomas, Univ. Gent (Belgium)

8627 0J Glass integrated optic Fourier transform spectrometer in the spectral bandwith 700 1000nm: process improvement [8627-19]

A. Creux, A. Morand, P. Benech, IMEP-LAHC (France); B. Martin, Resolution Spectra Systems (France); G. Grosa, IMEP-LAHC (France); C. Cassagnettes, D. Barbier, Teem Photonics S.A. (France); E. Le Coarer, Institut de Planétologie et d'Astrophysique de Grenoble (France)

8627 OK Multiplexed selective detection and identification of TCE and xylene in water by on-chip absorption spectroscopy [8627-20]

W.-C. Lai, The Univ. of Texas at Austin (United States); S. Chakravarty, Omega Optics, Inc. (United States); Y. Zou, R. T. Chen, The Univ. of Texas at Austin (United States) 
8627 OL Glass integrated nanochannel waveguide for concentration measurements [8627-21] E. Jardinier, D. BucCi, IMEP-LAHC (France); L. Couston, F. Canto, A. Magnaldo, Commissariat à l'Énergie Atomique (France); J.-E. Broquin, IMEP-LAHC (France)

8627 OM Sensing explosives with suspended core fibers: identification and quantification using Raman spectroscopy [8627-22]

G. Tsiminis, The Univ. of Adelaide (Australia); F. Chu, Shanghai Univ. of Electric Power (China); N. A. Spooner, The Univ. of Adelaide (Australia) and Defence Science and Technology Organisation (Australia); T. M. Monro, The Univ. of Adelaide (Australia)

\section{SESSION 6 ON CHIP RESONATORS}

8627 ON On-chip whispering-gallery-mode microlasers and their applications for nanoparticle sensing (Invited Paper) [8627-23]

S. K. Ozdemir, L. He, J. Zhu, F. Monifi, W. Kim, O. Kenechukwu, H. Yilmaz, S. H. Huang,

L. Yang, Washington Univ. in St. Louis (United States)

862700 Controlling the mode volume in high-Q microcavities with high refractive index coatings [8627-24]

A. J. Maker, B. A. Rose, A. M. Armani, The Univ. of Southern California (United States)

8627 OP Wavelength dependent vertical integration of nanoplasmonic circuits utilizing coupled ring resonators [8627-36]

M. Nielsen, A. Y. Elezzabi, Univ. of Alberta (Canada)

\section{SESSION 7 DIFFRACTIVE PHOTONICS}

8627 OS Tilted Bragg grating based optical components within an integrated planar platform [8627-28]

H. L. Rogers, C. Holmes, K. R. Daly, L. G. Carpenter, J. C. Gates, G. D'Alessandro,

P. G. R. Smith, Univ. of Southampton (United Kingdom)

8627 OT Phase modulated direct UV grating writing technique for ultra-wide spectrum planar Bragg grating fabrication [8627-29]

C. Sima, J. C. Gates, H. L. Rogers, P. L. Mennea, C. Holmes, M. N. Zervas, P. G. R. Smith,

Univ. of Southampton (United Kingdom)

8627 OU Nano-scale and multi-functional Bragg-grating structures for photonic device applications [8627-30]

A. S. Jugessur, The Univ. of lowa (United States)

8627 OV A transpose optical interconnect utilising metamaterial Luneburg waveguide lenses for switch fabric on-a-chip applications [8627-31]

H. Nikkhah, T. Hall, Univ. of Ottawa (Canada)

8627 OW Generation of surface plasmons with compact devices (Invited Paper) [8627-32]

A. Baron, P. Lalanne, C. H. Gan, J. P. Hugonin, Institut d'Optique, CNRS (France) 
8627 0X Plasmonic modulator based on thin metal-semiconductor-metal waveguide with gain core [8627-33]

V. E. Babicheva, R. Malureanu, A. V. Lavrinenko, Technical Univ. of Denmark (Denmark)

8627 OY Metal-dielectric metamaterials for guided wave optics applications [8627-34]

N. Dubrovina, X. Le Roux, Institut d'Électronique Fondamentale, CNRS (France); S. Blaize, Univ. de Technologie Troyes (France); A. de Lustrac, G. Lerondel, A. Lupu, Institut

d'Électronique Fondamentale, CNRS (France)

862710 Equivalent circuit model for plasmonic slot waveguides networks [8627-39]

M. A. Swillam, The American Univ. in Cairo (Egypt); C. Lin, A. S. Helmy, Univ. of Toronto

(Canada)

\section{SESSION 9 MODELING}

862711 Efficient design of photonic integrated circuits (PICs) by combining device- and circuitlevel simulation tools [8627-37]

C. Arellano, VPIphotonics GmbH (Germany); S. Mingaleev, VPI Development Ctr. (Belarus); I. Koltchanov, A. Richter, VPIphotonics GmbH (Germany); J. Pomplun, JCMwave GmbH (Germany); S. Burger, F. Schmidt, JCMwave GmbH (Germany) and Konrad-Zuse-Zentrum für Informationstechnik Berlin (Germany)

862712 Efficient optimization of nanoplasmonic devices using space mapping [8627-38] P. Dastmalchi, G. Veronis, Lovisiana State Univ. (United States)

862713 Robust optimization of $2 \times 2$ multimode interference couplers with fabrication uncertainties [8627-40]

S. U. Rehman, M. Langelaar, F. Van Keulen, Technische Univ. Delft (Netherlands)

862714 Equivalent step-index model of multifilament core fibers [8627-41]

R. Spittel, A. Lorenz, S. Jetschke, M. Jäger, H. Bartelt, Institute of Photonic Technology

(Germany)

\section{POSTER SESSION}

862716 AWG-Parameters: new software tool to design arrayed waveguide gratings [8627-42] D. Seyringer, Vorarlberg Univ. of Applied Sciences (Austria); M. Bielik, Slovenska Technicka Univ. (Slovakia)

862717 Two-dimensional finite-element analysis of tapered segmented structures [8627-43]

R. Rubio Noriega, H. Hernandez-Figueroa, Univ. Estadual de Campinas (Brazil)

862718 Calculation of defect modes in index contrast of $\mathbf{A l}_{\mathbf{x}} \mathbf{G a}_{1-\mathrm{x}} \mathbf{A s}$ waveguides [8627-44]

L. M. Ali, F. A. Abed, Erbil Technical Institute (Iraq)

862719 Integrated surface plasmon resonance resonator using silicon on insulator [8627-45] G.-Y. Oh, Chung-Ang Univ. (Korea, Republic of); D.-G. Kim, S. H. Kim, H. C. Ki, T. U. Kim, Korea Photonics Technology Institute (Korea, Republic of); H.-S. Kim, T.-K. Lee, B.-H. Lee, Y.-W. Choi, Chung-Ang Univ. (Korea, Republic of) 
8627 1B Integrated-optic polarization controllers based on polymer waveguide [8627-48]

J.-W. Kim, S.-H. Park, W.-S. Chu, M.-C. Oh, Pusan National Univ. (Korea, Republic of)

8627 1C Near infrared tunable lasers based on flexible polymeric Bragg reflection waveguide devices [8627-49]

N.-S. Son, K.-J. Kim, J.-W. Kim, C.-H. Sung, M.-C. Oh, Pusan National Univ. (Korea, Republic of)

8627 1E Impact of thermal oxidation, surface chemistry and porous silicon morphology for sensing applications [8627-51]

I. A. Kolmychek, D. A. Kopylov, T. V. Murzina, Lomonosov Moscow State Univ. (Russian Federation); F. Baldini, S. Berneschi, Istituto di Fisica Applicata Nello Carrara (Italy);

D. Farnesi, Istituto di Fisica Applicata Nello Carrara (Italy) and Museo Storica della Fisica e Ctr. Studi e Ricerche Enrico Fermi (Italy); A. Giannetti, S. Tombelli, G. Nunzi Conti, S. Soria, Istituto di Fisica Applicata Nello Carrara (Italy)

$8627 \mathrm{IF}$ Arrayed waveguide grating using the finite difference beam propagation method [8627-52]

M. C. F. Toledo, M. I. Alayo, Univ. de São Paulo (Brazil)

Author Index 


\title{
Conference Committee
}

\author{
Symposium Chair
}

David L. Andrews, University of East Anglia Norwich (United Kingdom)

Symposium Cochairs

Alexei L. Glebov, OptiGrate Corporation (United States)

Klaus P. Streubel, OSRAM GmbH (Germany)

Program Track Chair:

Yakov Sidorin, Quarles Brady LLP (United States)

Conference Chairs

Jean Emmanuel Broquin, IMEP-LAHC (France)

Gualtiero Nunzi Conti, Istituto di Fisica Applicata Nello Carrara (Italy)

Conference CoChairs

Pierre Berini, University of Ottawa (Canada)

Christoph M. Greiner, LightSmyth Technologies, Inc. (United States)

Conference Program Committee

Pavel Cheben, National Research Council Canada (Canada)

Xudong Fan, University of Michigan (United States)

Sonia M. García-Blanco, Universiteit Twente (Netherlands)

Helmut Heidrich, Fraunhofer-Institut für Nachrichtentechnik Heinrich-HertzInstitut (Germany)

Andrea I. Melloni, Politecnico di Milano (Italy)

Robert L. Nelson, Air Force Research Laboratory (United States)

Min-Cheol Oh, Pusan National University (Korea, Republic of)

François Royer, University Jean Monnet Saint-Etienne (France)

Jens H. Schmid, National Research Council Canada (Canada)

Frank Schmidt, JCMwave GmbH (Germany)

Yakov Sidorin, Quarles Brady LLP (United States)

Stefano Taccheo, Swansea University (United Kingdom)

Christoph Wächter, Fraunhofer-Institut für Angewandte Optik und

Feinmechanik (Germany)

Qiwen Zhan, University of Dayton (United States) 


\section{Session Chairs}

OPTO Plenary Session

David L. Andrews, University of East Anglia Norwich (United Kingdom)

Alexei Glebov, OptiGrate Corporation (United States)

$1 \quad$ Waveguide Engineering I

Jean Emmanuel Broquin, IMEP-LAHC (France)

2 Photonic Integration

Yakov Sidorin, Quarles Brady LLP (United States)

3 Waveguide Engineering II

Stefano Taccheo, Swansea University (United Kingdom)

4 On Chip Active Devices

Gualtiero Nunzi Conti, Istituto di Fisica Applicata Nello Carrara (Italy)

5 Sensors

Xudong Fan, University of Michigan (United States)

6 On Chip Resonators

Gualtiero Nunzi Conti, Istituto di Fisica Applicata Nello Carrara (Italy)

7 Diffractive Photonics

Silvia Soria, Istituto di Fisica Applicata Nello Carrara (Italy)

8 Plasmonics

Jean Emmanuel Broquin, IMEP-LAHC (France)

9 Modeling

Sven Burger, JCMwave GmbH (Germany) 


\section{Introduction}

Whether you are a confirmed scientist or a student, whether you are an academic or working for a company, you will find in these proceedings of the seventeenth Photonics West conference on Integrated Optics a picture of this still evolving, dynamic and exciting field.

When building this year's conference, we tried to reflect that aspect by keeping a great diversity in the session topics as well as in the technologies and concepts presented. Indeed, if polymeric waveguides and glass ion-exchanged ones were treated with the same interest as the new fast-developing Silicon Photonics devices, it is because we believe that the cross-fertilization of ideas is one of the keys to major breakthroughs in science.

In these proceedings, the reader will therefore see a wide range of exciting advances ranging from new optofluidic devices for nuclear waste management, to different approaches for exciting efficiently plasmonic waveguides, as well as resonators or rare-earth-doped lasers for airborne lasers.

He will also find articles written by students, who quite often gave their first international talk at this conference, together with papers from renowned scientists of the field. It is indeed because today's students are tomorrow's scientific leaders that our conference always promoted their participation and will keep on doing so thanks to the SPIE student grant policy.

If Integrated Optics: Devices, Materials, and Technologies is one the oldest conferences of the SPIE OPTO symposium, it is, of course, because of the quality of the scientific work that had been presented through the years, but it is also because of the dedication of all the members of the program committee who accept willingly to spend a part of their summertime in building this conference and finding all the exciting invited talks that we see every year.

To them, to all the speakers and authors, to all the SPIE staff who makes the logistics run so smoothly, we would like to say thank you very much and we long to see you next year.

Jean Emmanuel Broquin Gualtiero Nunzi Conti 